\title{
Hungarian Language and Law: Developing a Grammar for Social Inclusion, a Vocabulary for Political Emancipation. Special Issue (IJSL)—Editorial Preface
}

\author{
Mate Paksy ${ }^{1} \cdot$ Miklós Szabó $^{2} \cdot$ Edina Vinnai $^{2}$
}

Published online: 28 August 2020

(c) The Author(s) 2020

\begin{abstract}
Having been invited by editor-in-chief, Professor Anne Wagner, to edit the present special issue, we decided to fulfil a longstanding wish to provide a panorama about the Hungarian Language and Law. Along with other 'law and ...' movements, Law and Language has attracted a great deal of attention from subsequent generations of Hungarian academic lawyers, because the political transition served as a wonderful subject and context for scholarly papers and text books, for examining the putative or real influence of this or that popular social scientist or for undertaking literature overviews. Unfortunately, there have been relatively few academic papers that have sought to draw general conclusions from empirically well-founded case studies. In order to fill that important gap, this special issue has taken the opportunity to select only those interdisciplinary papers whose goals include an analysis of Hungarian legal discourse written from a critical angle and using critical empirical methodology. At the very outset of the editing process-back in 2018-for the purposes of this special issue we defined as 'empirical' any sufficiently coherent factbased research that reflects the language of legal discourse. And 'critical' means an engagement with the values of the Rule of Law. This double methodological and axiological feature is manifest throughout the selected papers classified as 'law and language'.
\end{abstract}

Edina Vinnai

jogvinni@uni-miskolc.hu

Mate Paksy

mate.paksy@gmail.com

Miklós Szabó

jogszami@uni-miskolc.hu

1 University of Paris-Nanterre, Paris, France

2 University of Miskolc, Miskolc, Hungary 


\section{Introduction}

Having been invited by editor-in-chief, Professor Anne Wagner, to edit the present special issue, we decided to fulfil a longstanding wish to provide a panorama of the Hungarian Language and Law.

In 1989, after the fall of communism, the democratic transition to the Rule of Law in Hungary was given a warm welcome by Western political communities. Astonishingly enough, it took fifteen long years before the country finally, in 2004, along with other European countries, became a member of the European Union, having shown that it could meet the Copenhagen criteria, which require the stability of democratic institutions and respect for the Rule of Law. Another fifteen or so years on-how time flies!-in 2020 the poster child for illiberal democracy is Hungary, and Western political communities seriously question whether it still fits within the European community of the Rule of Law or Rechtsstaat (in the Hungarian constitutional language, jogállam is a direct translation of this German legal term [36]).

Along with other 'law and ...' movements, Law and Language has attracted a great deal of attention from subsequent generations of Hungarian academic lawyers, because the political transition served as a wonderful subject and context for scholarly papers and text books, for examining the putative or real influence of this or that popular social scientist or for undertaking literature overviews. Unfortunately, there have been relatively few academic papers that have sought to draw general conclusions from empirically well-founded case studies. In order to fill that important gap, this special issue has taken the opportunity to select only those interdisciplinary papers whose goals include an analysis of Hungarian legal discourse written from a critical angle and using critical empirical methodology. At the very outset of the editing process, back in 2018 , for the purposes of this special issue we defined as 'empirical' any sufficiently coherent fact-based research that reflects the language of legal discourse. And 'critical' means an engagement with the values of the Rule of Law. This double methodological and axiological feature is manifest throughout the selected papers classified as 'law and language'.

Foreign readers should bear in mind that the legal disciplines closest to 'law and language' are legal theory and legal history. A quite recent development-traceable back to when Hungary joined the multilingual European Union-is that linguists have started to show an interest in legal texts and discourses without being equipped with knowledge of legal theory or history. In brief, what we call 'law and language' is part of legal theory. Applying mutatis mutandis Bobbio's distinction between lawyers' legal philosophy and philosophers' legal philosophy, we may dub our special issue lawyers' 'law and language' rather than linguists' 'law and language' [3].

\section{Transition to the Rule of Law and the Debates in Legal Theory}

The main challenge today in law and language as a critical social science is to assess empirically cases where vulnerable people participate in legal discourses; they are the ones who really have to deal with the lack of a new grammar that attempts better 
social inclusion, and a new vocabulary for a more extended political emancipation. Therefore, those scholars who belong to and contribute to law and language have been called upon by the political context to introduce a critical perspective. Globalist, communitarian and conservative scholars have sparked serious debate about whether the citizenship law in Hungary is doing enough to come to terms with the legal treatment of ethnicity. Since the failed referendum on dual citizenship, every aspect of ethnicity as a cultural feature has come again and again under the spotlight. The extension of Hungarian citizenship to those who claim to be Hungarian in the ethnic sense (and who speak Hungarian, too), but who do not have a permanent address on the territory of Hungary, is discussed in detail by an excellent paper in this special issue, written by Zsolt Körtvélyesi [21].

Scholars overwhelmingly agree that constitutional amendments made during the transition period were fully in keeping with the requirements of legality; but they also agree (with a handful of exceptions) that the political basis for these amendments, and hence their legitimacy, was flawed. The plans for transforming the Constitution of 1949 into a Rule of Law or Rechtsstaat were delineated at the National Roundtable Talks of 1989 between the democratic opposition and the state party. Since most of the members of the democratic opposition were unelected, and since the ruling Communist Party still held power on the basis of the last (undemocratic) election before the fall of communism, the legitimacy of the roundtable was fairly fragile. It is important to remember that no referendum was held to confirm constitutional amendments.

As an important milestone in the transition, the old-new Constitution came into force on 23 October 1990, and the Constitutional Court began its work. The first paragraph of Article 2 of the Constitution declared that the Hungarian Republic was an independent and democratic state governed by the Rule of Law. According to the Constitutional Court, the Rule of Law was a legal fait accompli and an unfinished political programme, and therefore the public authorities were obliged to respect this value. This view gained endorsement from the fact that the Constitution was the supreme legal norm, situated at the apex of the legal hierarchy. Constitutional judges proudly declared that Article 2 of the Constitution was not a state-goal or a political declaration, but a legal rule; therefore, any contrary act was deemed unconstitutional.

Chief judge Sólyom, previously a member of the democratic opposition, drew inspiration both from the German constitutional tradition (interpreting the Constitution as if it were a seamless logical unit) and from Ronald Dworkin's idea of a moral interpretation of the Constitution, and he deduced new rights from the abstract constitutional rules on the right to life and the right to human dignity. As to the Rechtsstaat, the fundamental paradox revealed by the Constitutional Court in the 11/1992 decision was that the freely elected new parliament could not build a Rechtsstaat unless the means used were in harmony with the idea of the Rechtsstaat. The decision on retroactivity — which declared unconstitutional the law dealing with past delicts committed by the state and its officials during communism-stated that the Rechtsstaat implied that the objective value of legal security was ranked higher in the hierarchy than the subjective value of justice; therefore those crimes that went unpunished during the communist regime could not be punished retroactively. Ever 
since then, people in Hungary have viewed Rechtsstaat as a meaningless, empty concept, used by lawyers and politicians alike as a weapon in their political squabbles.

\section{Law and Language as Legal Theory: A Clash Between Moderate Post-Marxists and Iconoclastic Neo-Wittgensteinians}

Legal theory has never been either insular or isolated from other legal disciplines. In Hungary, during the 1990s, two main schools emerged to occupy the leading position in the linguistic analysis of law: moderate post-Marxism, on the one hand, and iconoclastic neo-Wittgensteinianism, on the other.

In order to understand better the position of post-Marxism, it seems worth taking a step back towards its origins, and drawing a distinction between Marxism and Stalinist communism. Stalin's manifestations in questions of linguistics are well known. Between June and August 1950, he published three public letters to the editor of Pravda, as one of the participants in the debate on Marxism and linguistics. On the surface, the debate was an academic clash and reckoning between Marxism and 'Marrism'. Nikolai Y. Marr was a linguist who had developed a theory of 'Japhetic', viz. the name of the ancient language, based on final ancient elements of language: sal, ber, yon and rosh. In the debate, Stalin sought to clarify the place of language vis-à-vis the superstructure of society. As the first claim of his first letter stresses,

"[t]he base is the economic structure of society at the given stage of its development. The superstructure is the political, legal, religious, artistic, philosophical views of society and the political, legal and other institutions corresponding to them. Every base has its own corresponding superstructure. [...] If the base changes or is eliminated, then, following this, its superstructure changes or is eliminated; if a new base arises, then, following this, a superstructure arises corresponding to it. In this respect language radically differs from the superstructure." [31: 1]

Considering that law is an outstanding member of the superstructure, Stalin's thoughts on linguistics can hardly be seen as useful to a Marxist theory on law and language, since Stalinist Marxism requires law to be determined directly by the economic system, without taking into account the fact that language should mediate between the economic and the legal sectors. This was clear to Hungarian academic circles as early as November 1950 — one of the worst years of the totalitarianismand a conference was organized by the Hungarian Academy of Sciences on implementation of Stalin's articles on linguistics [24]. On behalf of legal scholarship, one speaker was Imre Szabó, the Kronenjurist of the Stalinist era. His speech sought to eliminate the linguistic aspect of law by focusing exclusively on law as a constituent part of the superstructure. It was hinted that the new political regime needed a new law immediately, and that it was the obligation of academic lawyers to create it. Earlier legal—and linguistic — categories needed to be deleted. Two commentators-Géza Marton, a Roman lawyer, and Endre Nizsalovszky, a civil lawyer-were sufficiently brave to stand up to Imre Szabó's dogmatic Stalinism. They argued that law and language develop together, and even though law is a constituent part of the 
superstructure, legal terminology, legal institutions and legal rules are more tenacious. Marton and Nizsalovszky determined, indeed, the anti-Stalinist Marxian or post-Marxian standpoint: if one sticks to the doctrine of law-in-superstructure, then one has to forget about the linguistic nature of law. That is why topics of law and language were rarely cultivated during the decades of socialism.

Marxian and post-Marxian scholars-who, following Lukács's late and unfinished masterpiece, the Ontology-have considered the law as a means of mediating between the base and the superstructure of society. Norms of law were held by them to be linguistically articulated orders of the state-or of the ruling class (which is the same). This conception may be called 'Rule of Norms' - an unconditional insistence on obedience to the norms of the central authorities. From the early seventies, this school became the so-called socialist normativism, the official scientific ideology of the communist era under the political system of János Kádár. Being 'scientific' ideology, the constitutionalist ideas of the Rule of Law (Rechtsstaat) remained outside the discourse. Some historical reasons may explain this condemnation. Under the Russian occupation of Hungary, the first written Hungarian Constitution was finally enacted in 1949 as a simple statute. Essentially a translation from the Russian of Stalin's 1936 Constitution, nowhere did it contain any reference to the Rechtsstaat. Until the amnesty for those people caught up in the anti-Soviet Uprising of 1956 and the subsequent repression, the Rule of Law was basically banned from legal vocabulary. Moving very slowly, and constantly keeping an eye on Moscow's directives, the Covenants on Civil and Political Rights and on Economic, Social and Cultural Rights formally came into force in Hungary in 1976, without any legal enforcement or institutional support. When Russian lawyers finally started to speak about a socialist or Marxist-Leninist Rechtsstaat, Hungarian lawyers borrowed the concept from the Soviet Union. The dominant academic doctrine of public law qualified individual rights as mere goals of the state, the enforcement of which could not be a matter for the courts. Because of the ideology of socialist normativism, the socialist doctrine of the Rechtsstaat encompassed neither the idea of the constitution as a legal norm at the pinnacle of the legal hierarchy nor the principle of the separation of powers.

This is an ambivalent legal theory-not only in a historical perspective, but also in itself. The doctrine as opposed to bourgeois law served as official justification for socialist law. Compared to other schools of legal thought, it was born in 1936. For classical Marxists, law and socialism is a contradiction in terms, since something is either law (but then not socialist) or socialist (but then not law-rather some sort of technical rules). The reason is that in Marxist critical philosophy, law is a tool in the hands of the ruling (bourgeois) class and serves to perpetuate to exploitation and oppression of the repressed (labour) class. The existence of law depends on the existence of private ownership of capital goods and socialism/communism is the very negation of this institution [11]. Andrey Yanuaryevich Vyshinsky became public prosecutor of the USSR and head of the academic Institute of Soviet Construction and Law (later the Institute for State and Law), previously headed by Evgeny B. Pashukanis. The latter was ousted as a 'public enemy' and was subsequently executed in September 1937, having been charged with being a 'Trotskyite saboteur'. 
So, Vyshinsky stepped forward as the representative figure of Soviet jurisprudence [44].

How was it possible for Vyshinsky's doctrine to remain part of the legal scholarship of the Socialist countries? The answer is similar to the answer to the question: How was it possible for Hungary to have its Stalinist constitution until 2011? It is partly because this heritage had a certain 'Potemkin nature' and partly because it reflected real needs and challenges. The first consideration meant that the codification wave of the late 1930s (which served as a template for the 1949 Hungarian constitution) tried to show a nice face to the world: everyone is the same and things are even better than in the West. True, the 1930s and the 1950s were the decades of the show-trials, but the 'law in books' revealed a nice facade that covered the 'law in action'. The second consideration refers to the unexpressed realization of the fact that, by their nature, modern societies (and those yet to be modernized) have certain characteristics in common. In the Weberian sense, the so-called 'modernity' emerges through bureaucratic organizations, which again need formal and rational law as organized coercion. The Vyshinskyan conception of law fits legal formalism, sensu largo. That is, theoretical reflections of these characteristics found a ready home in Western theories like legalism or Gesetzespositivismus; imperative and coercive theories of law; social theories of law; functional (social control) and instrumental (social engineering) theories of law-all of them reflect a certain picture of society. And so, the heritage is a version of legal theory embedded in social theory (adorned with references to the works of Marx, Engels and Lenin) [32].

Needless to say, ordinary citizens were not involved personally in the problem of the base and infrastructure of society. In order to understand observance of the law of the communist regime, it seems opportune to go beyond the legal discourse and tackle the question of legitimacy. This is a sociological and moral question, rarely discussed by social theories of law in Hungary. So, in brief, why did Hungarian citizens obey the law of the pseudo-Rechtsstaat in the decades before 1989? Clearly, it was not just the presence of a Russian military force that provided the regime with overall legitimacy: the demos itself did that, by virtue of its tacit collaboration with the ruling class. This argument is somehow reminiscent of Vaclav Havel's semantical theory of the shop window. Havel imagined a shop owner during the early eighties in, say, Prague. The owner appears to be satisfied with his small business, which for the moment is not bothered by the communist authorities. But of course, he wants a better life for his two children, without having to emigrate to the West. Thus, in order to guarantee their admission to university, he has displayed in his shop window a card—neither ridiculously small nor exaggeratedly large-loyally proclaiming 'Long live the Communist Party!' His rationalistic strategy is typical of other shopkeepers in the streets of Prague. Therefore, those who regularly walk by become accustomed, little by little, to seeing this landscape of cards in the shop windows. Havel claimed that the legitimacy of socialist society was aided and abetted by this landscape of collaboration. (Havel is discussed by János Kis [19]).

The change of political system, in a way, consists of translating one language to another at a macrolevel (politics), as well as at a microlevel (secret agencies). The analysis provided by Béla Révész on the language of the secret agency before 1989 implies also the problem of how to come to terms with the past using a new 
language to evaluate former linguistic practices [29]. A new start could come with new generations after the 1989 transitions. Social theoretical frames took the place of Marxian paradigm, and those who were not satisfied with that opened their eyes to practical philosophy. Now, practical philosophy understands law as authoritative praxis and, from another point of view, linguistic praxis. We may add that Marxism did not exclude this approach, either. For instance, Valentin N. Voloshinov, in his Marxism and the Philosophy of Language, offered such an approach as early as 1929, also handling the problem of the relationship of the base and superstructures [43: 17ff]. We might also recall the work of Roman O. Jakobson or Mikhail M. Bakhtin from the same epoch. Followers of the approach of 'practical-philosophy-as-linguistic-analysis' may be dubbed neo-Wittgensteinians, referring to the linguistic turn and its philosophical implications. A kind of proof of the possible interruption between pre- and post-communist legal theory is that the iconoclast neo-Wittgensteinianism, as exemplified by Matyas Bodig [4] dared to vehemently criticize and refute the hermeneutical approach of the former regime's leading legal scholar, Vilmos Peschka. Unfortunately for us, the neo-Wittgensteinian iconoclasts from Hungary were invited to conduct their research and to teach in foreign countries, and therefore they left the country for good. Thus, the post-Marxian social theory of law had no competing school of thought in the law schools, and-forgetting all the critical aspects of Marxist legal thought—evolved on occasion into ideological support for the new illiberal or authoritarian regime.

A fruitful way of handling linguistic aspects of law is to use the distinction between the concepts of 'surface structure' and 'deep structure', as introduced by Noam Chomsky [5, 6]. In reviewing his works and significance, John R. Searle uses, as an example, the sentence: 'I like her cooking.' He says:

'In spite of the fact that it contains no ambiguous words (or morphemes) and has a very simple superficial grammatical structure of noun-verb-possessive pronounnoun, this sentence is in fact remarkably ambiguous. It can mean, among other things, I like what she cooks, I like the way she cooks, I like the fact that she cooks, even, I like the fact that she is being cooked' [30: 17].

The problem to be handled within law is similar to handling 'syntactically ambiguous' sentences; for example, while the meaning of 'dog' may be completely clear, it may be doubtful if a 'goat' or a 'cow' is considered a 'dog' by the sign: 'No dogs in restaurant.' Normative sentences like this are practically, or pragmatically, ambiguous. Chomsky's solution is that, in order to resolve (syntactical) ambiguities at the surface level of linguistic expressions (utterances as they are), one should bore down to their deep structure-we would say to their logical structure. Deep structure and surface structure are connected by transformational rules (e.g. by creating different grammatical structures to express the same possessive relation). This also means that the meaning of (surface) sentences is determined by their deep structures, and that surface structures are connected to each other by their deep structures. So, both the interlingual and the intralingual transformation/translation of sentences is made possible by the medium of deep structure. 


\section{Natural Law and the Origin of the Linguistic Problem}

Over the centuries, the space that 'remained' after the Tripartitum was 'occupied' by legislation: in our case, Habsburg imperial charters and decrees; the introduction of the 1812 Austrian Civil Code (AbGb: Allgemeines bürgerliches Gesetzbuch) in Hungary; the 1861 Provisional Rules of Administration of Justice, compiled by a committee of the Curia (Supreme Court) and approved by the Diet (but not so by the monarch); and the Draft Civil Codes of 1900, 1913 and 1928, bearing a strong German imprint. (The first Hungarian Civil Code was finally enacted in 1959.)

Although the natural law-inspired Austrian Civil Code had a huge influence on the Hungarian legal mind, the code provoked hostility toward rationalist natural law doctrines among those defending national legal-cultural traditions. Since the inspiration to modernize local law came from German law, rather than the imposed Austrian law, the influence of the teaching of the Historical School and of the Begriffsjurisprudenz on Hungarian legal scholars had at least the same weight as natural law. The discourse of lawyers and politicians at the end of the nineteenth century is the subject of Mate Paksy's study that puts the Austro-Hungarian Compromise and the Canadian British North America Act in the historical perspective of comparative public law [26].

Regarding the deep, universal structure of law, we may be reminded of the ancient thinking of natural law. Until the emergence of the new, illiberal regime, natural law was never the 'official' legal doctrine, but nor was it officially condemned (as in Italy or Spain). It is no surprise that nobody talked about its rebirth either (as they did in Germany). On the other hand, strangely enough, a great number of concepts in earlier and present Hungarian codes and statutes have a natural law pedigree. One can even find natural-law-like arguments in the case law of private and constitutional adjudication, and it is commonplace to say that natural rights theories have widely permeated current legal-political thinking in Hungary.

The opening chapter of the story of natural law coincides with the early linguistic transformation of Hungarian law. The Opus Tripartitum, edited by Stephen Werbőczy (1458-1541), 'a sixteenth-century Hungarian Bracton' [28: 135], assistant judge at the Royal Court, adopted a great number of terms from ius commune, starting with ius naturale. King Vladislaus II requested Werböczy to fulfil the 'task of gathering together all the rights, laws, and customs, and the received and approved constitutions of this our kingdom'. The work was completed between 1504 and 1514 under the title Tripartitum opus juris consuetudinarii inclyti regni Hungariae (Customary Law of the Renowned Kingdom of Hungary in Three Parts) [45]. It was placed before the Diet (viz. the central political gathering) of 1514, which approved it; it also received the royal assent, but it was never promulgated or introduced. Finally, Werbőczy printed his collection at his own expense in Vienna in 1517 and had copies distributed across the counties. The Tripartitum gained its authority from the administration of justice and (in some places) remained in effect into the twentieth century. After a few false starts between 1458 and 1527, a further process was launched in 1584 to collect and publish the (parliamentary) decrees: Decreta, Constitutiones et Articuli inclyti Regni Hungariae. See [8: 7-8]. 
The term ius naturale appears clearly at the very beginning of the book. The role of the law is to realize justice; legal science serves the law and justice. (Intr. 5) However, Werbőczy's definition of law as a decree of the people, based on a common decision of nobles and commoners (Intr. 6,1) is rather positivist. On the other hand, enacted law has to be in harmony with divine law, and this is particularly important since "if the law is already issued, judgments have to be made according to it and not about it" (Intr. 6, 13). Werböczy was, however, convinced that there was no sanction that would make a law void because it was contrary to natural law. The rule of the salvo semper divino naturalique iure reminds the reader of a paragraph in the introduction, where he explains that laws cannot completely neglect natural and divine law, but they can draw some distinctions.

As to the language of the law, in the case of Tripartitum, it was given: Latin-the official language in Hungary until as late as 1844 . The language brought the terminology and taxonomy with it - and was backed by Roman law:

'Since every legal custom which we use always concerns either persons or things or actions, but it is certain that all laws were established for the benefit of persons, it seems proper to start the treatment of the matter at hand with the law of persons, and then to discuss the other two parts of customary law (not always in a direct order, however, but sometimes in a reversed one, as is required by the nature and pattern of issues coming before the courts). For this reason, I thought it best to divide the present work into three parts."

Clearly, the division comes from Gaius' Institutiones [15]. The impact of the Institutiones genre is also evident in the mode of explication: the titles serve as questions (e.g., Tit. 7. Quare factae sunt leges?-Why are there laws?) followed by the answer (here: de quadruplici officio legis-on four functions of laws). And the four functions are familiar from Digesta: omnis lex aut permittit, aut vetat, aut punit, aut imperat - each law either permits, or forbids, or punishes, or commands. (Tit. 7. $\S 3$.) It is likely that a study-book popular at the time also served as a secondary source for Werbôczy [27, 39: 241-328]. And this way, together with the terminology and taxonomy, we get the institutions of Roman law, as well. Apart from terminology and conceptual content, the Tripartitum is said to hamper the direct, full and real adoption of Roman law [17: 79-80].

András Földi's scrutiny of 'false friends' seeks to trace the problem with the translation of legal terms back to Roman law [13]. Probably unintentionally, this paper will send the reader an important message: Roman law has survived political regimes and is present even in the current language of lawyers-judges, professors, and barristers alike-who should bear this in mind when applying legal texts to a particular case, either because the meaning of the Roman law is the same as the legal term used according to Hungarian law or because the meaning is different, despite of the same Latin term. First, Werbőczy's impact was mediated by medieval canon law and civil law, and by commentators such as Bartolus; second, the GraecoRoman heritage arrived with German-Austrian intermediation; third, it was all seriously distorted by the incorporation of Hungarian customs. Let me quote the closing words of the Tripartitum, Part 1, Ch. 1, Sect. 1.: 
"I had to remember that all I had written in this Tripartitum would only be used by our fellow countrymen. That is why I believe I did the right thing when, in my work, I preferred words used in Hungary over those used in Latium. Because in such things (as is witnessed by Aristotle, too) we have to speak as the majority does."

Yet, Werbőczy did not follow the Gaian system mechanically. His first book contained the private (civil) law of nobility; his second, the norms of (mostly civil) procedure appropriate to Book I; and 'the rest' remained for the third book: the particular laws of regions, of citizenry, and of villeinage.

The first edition of Tripartitum, in 1517, was followed by several more (43 up to the time of the 1896 Millennial edition). Actually, these editions were not simple collections, but rather inter- and intra-lingual translations. (The distinction of inter-semiotic and inter-lingual, as well as intra-lingual translation, was introduced by Roman Jakobson. [18: 232-239]) For instance, the concept of dos in Roman law meant dot/dotation/dowry, whereas in the Tripartitum (under the influence of canon and German law) the meaning became reduced to the dower [16: 219-20]. Used as a source of law, it is no wonder that Parliament decided on the revision and rewording of the Tripartitum in 1548, and then again in 1553 (when the revising committee put an amended Quadripartitum on the table), 1563, 1608-09, 1715, 1719all these being intra-lingual translations of the (official) Latin-language opus. The first translation into Hungarian, published in 1565, tried to prepare the ground for the elaboration of a Hungarian legal language - without success: these days, readers can barely cope with the text. The next important step was taken in 1611 by Gáspár Heltai Jr. As the most popular and influential translator of the Holy Bible into Hungarian (1551-61), he triggered the development of a Hungarian literary language. The vernacular language started to blossom, and with it so did the linguistic capacity to deal with legal texts. However, the elaboration of a comprehensive legal language, suited to professional use, was still hampered by the fact that the official language remained Latin. It took until the first half of the nineteenth century for this to change. But once when it did change, there was a burst of linguistic reform. The Hungarian Academy of Sciences was founded in 1825 and was empowered by Act XI of the 1827 decree "for the cultivation of the vernacular" to turn the Hungarian language into a medium capable of modernizing society. The efforts of the "neologism movement' were embodied in a series of terminological vocabularies and lexicons, offering tens of thousands of terms in place of (mostly) Latin and German expressions. After a 'struggle for life' among the various suggestions, by the end of the century the movement had come to rest. Notwithstanding the renewal of Hungarian legal language culminated in a huge six-volume terminological lexicon, [23] and with some changes and additions, it has remained the terminological basis of our language use in law.

Of course, the 'Hungarization' of the legal language is nothing but the surface of law. Legal institutions as well as their conceptual content, the ideas and methods that make the law work are all embedded in Roman-German and-ultimately-in Roman law. Although a research on this might be very intriguing, we can only touch here on the problem of a 'socialist legal family'. When René David classified this 
'family' as one of the major legal systems, it might have seemed historically durable [9]. But looking back from today's perspective, the fact that it existed for just four decades in Eastern Europe-and for just seven in the Soviet Union-proves that 'socialist legal family' was only an aberration. And what is worthy of noteat least in Eastern-Central Europe-is the smoothness of the transition from the Roman-German to the 'socialist legal family' and back again. That could only be possible because there was no real transition; what was called the 'socialist legal family' was nothing more than a circumscribed, limited system-another kind of leges barbarorum.

\section{Translation as a Problem and European Integration}

Not surprisingly, more than half of the papers selected for this special issue treat the problem of translation. Whereas translation was recommended at the end of the nineteenth century because of the invention of a vernacular (Hungarian) legal language, this time the need for translation may be regarded as a side effect of European integration. Both Fuglinszky \& Somssich, and Herbert Küpper tackle the delicate problem of the translation of Hungarian legal terminology into a foreign language and vice versa. Ádám Fuglinszky \& Réka Somssich focus on the new Hungarian Civil Code and the practical solutions that were chosen when the Code was translated into English [14]. Herbert Küpper's research interest extends to all fields of Hungarian legal scholarship, and his paper deals with the linguistic problems involved in the translation of legal concepts from Hungarian law and the Hungarian language [22].

Political integration has taken place within Europe, and has involved legal and linguistic integration - at least integration of the national languages of law which means at least their translatability. The superficial challenge posed by multilingual political communities is clear for all to see, and it would seem that the technical tools of professional interpretation are capable of rising to this challenge, as in the European Union. Yet, the core of the problem lies deeper, namely at the roots of implementation of law. This process of implementation can be best modelled as translation, that is any transformation of a message expressed in one code into the same message expressed in another code. In short, translation is a change of codes [33]. The transformation of one particular linguistic expression into another is called translation in the broad sense-in the sense of code-switching. As already mentioned, Roman Jakobson distinguished three types of translation: (1) inter-lingual translation is translation sensu stricto: the interpretation of linguistic signs with the help of another language; we have an expression or a text in one language (code) and translate it into another, e.g. from English into German; (2) inter-semiotic translation or transformation is translation sensu largo: interpretation of linguistic signs with the help of a non-linguistic system of signs; we have an expression or a text in a language and translate them into a non-verbal code, e.g. into pictures (as in comics or films); (iii) intra-lingual translation or rewording is translation sensu specifico: interpretation of linguistic signs with the help of the same language; we have an expression or a text in one language and 
translate it into a different expression or text in the same language, e.g. from legal English into ordinary English [18].

When reading Emőd Veress' paper on the legal education in Transylvania [40], we may bear in mind Umberto Eco's often cited words: "The language of Europe is translation" (though these words are not contained in the written version of Eco's lecture [10]). One step further and we find that the language of European law is translation, too: continuous translation of official materials into the official languages of the EU. The criterion for these translations is functional equivalence, or, within the world of law, institutional equivalence. [20] And another step leads to a recognition that the language of the law per se is translation [25, 33]. At this level, we find intra-lingual translations: translations of authoritative legal texts into (interpretative) propositions about their content; translations of (interpreted) norm-texts into individual 'case-norms' [12: 129ff] in conformity with the given case; translations of words of statements into the words of law; translations of the words of laws into the words of court decisions, etc. All that is going on within the same universe of discourse that we call law-our law.

Noam Chomsky's theory is often referred to as 'universal generative grammar'. It is grammar, as its main point is the recovery of rules-basically syntactical rules-which can explain the way of constructing an infinite number of grammatically correct sentences within a natural language. It is generative, as, according to it, the linguistic competence of native speakers is not simply the ability to apply rules as algorithms, but is instead the ability to generate an infinite number of sentences (some never even heard) using the (constructional and transformational) rules of a language. Finally, it is universal, as, according to Chomsky, man is a 'syntactical animal'-his brain is 'wired' to determine syntactical structures of linguistic competence. Besides the universality of mankind (and not independently of it) there exists the universality of languages. Building blocks for the linguistic construction of reality-in terms of syntax: time; the subject-predicate relation; the possessive; the imperative mood; active and passive voices, etc.- are common in every language and serve as a basis and precondition for transforming the surface structures of one language into another.

Taking into consideration the fact that constructions (e.g. institutions, concepts) of Roman law form the basic structure of legal systems-not only in the case of civil law, but also of common law-these constructions may serve as constituents of the afore-mentioned deep structure of law. What is more, patterns of Roman law are decisive not only for the formation of institutions of law, but for the language of law — of legal systems - as well. Bound up with the institutions inherited from the Romans, and only in part separate from institutional facts, language offers the same opportunity for translatability: namely Latin as the origin of each and every professional (technical) language of modern law. Different nations have faced the challenge of developing their own legal language at different points in their history. However, the appearance of the challenge was connected to the appearance of nation-states, of national systems (codes) of law, and of national literary languages-inspired by translations of the Bible into the national language. This only happened about three centuries ago (compared to the 20-25 centuries of history of Roman law). It is not surprising that the common roots of institutions of law, together with the common 
roots of Latin terminology, may aspire to provide a common plinth for modern systems and languages of law.

Legal languages - linguistic reflections of the conceptual-institutional structure of law-are only superficial phenomena of law, changing in space and time. So, the Hungarian legal language-which, unlike some other legal languages, underwent radical reform during the nineteenth century-does not have a strong impact on the way of legal reasoning. Reasoning is the way we think, speak, and argue about something. The way of reasoning is patterned culturally, so it reflects common culture. Tindale identifies three main patterns of argumentation which "may be characterized as the (geometrical) logical approach, the (anthropological) rhetorical approach, and the (critical) dialectical approach" [38: 17]. It is not too difficult to recognize the ancient, common, historical roots in them: tekhné logiké, tekhné rhetoriké, tekhné dialektiké. In the search for the roots of law and legal reasoning and argumentation, we arrive at Greek rhetoric. In the absence of professional lawyers, it was the orator's job to argue at court. As Aristotle taught: there are three kinds of rhetorical speech: deliberative, forensic, and epideictic. Of these-at least for the needs of books on rhetoric - the paradigmatic type was forensic. But rhetoric was more than one of the arts. For Aristotle, rhetoric integrated the arts: "that Rhetoric is composed of analytical science and of that branch of political science which is concerned with Ethics, and that it resembles partly Dialectic and partly sophistical arguments" [1: 1359b].

All this is not just the stuff of history. The inseparable intertwining of institutional substance and the linguistic-terminological legacy of Greek philosophy and Roman law results in the consequence that a change in form signals a change in content. As analysed in the case study by Péter Takács [37], a slight change in the name of a state-'Hungary', instead of the 'Republic of Hungary' - indicates change in the system of government. Hungary is no longer a republic in the same way as elsewhere or previously, even though the form of government has not turned into monarchy (or anarchy). This change can be compared to many others. First, the 'Republic' of the 1946 constitutional text was changed into 'People's Republic' in 1949 by the Stalinist Constitution. Secondly, as to the actual constitution of 2011, the political goal was to replace the constitutional texts of 1949—which amended almost entirely the constitution of 1949 and interpreted by the Constitutional Court extensively_with a 'Basic Law'. This very expression was chosen to cut free once and for all from the 'Stalinist' constitutional legacy. Ironically enough, while the legislature intended to create a rock-solid, unamendable, and long-lasting constitution, the chosen name-i.e. 'Basic Law' (Alaptörvény)—referred to the Grundgesetz of the Federal Republic of Germany (1949), which was a temporary legal text accepted by the Western part of Germany until the reunification of the country. In an illiberal democracy, 'basic law' sounds better than 'constitution', as the latter term may remind people of Western liberalism. Similarly, calling a democracy an 'illiberal democracy' shows that the chosen political structure is not a democracy as it used to be; instead, it is either a strong, populist version of democracy or a light version of an authoritarian political regime. Quod erat demonstrandum: these examples warn us that linguistic forms have never been content-neutral in Hungary. Just the opposite: changes in content are allied to, and expressed in, terminological changes; 
and if the Hungarian political community seeks to stick to the common European way of living together, Hungarian scholars need to insist on the common European heritage of language of the law, too.

\section{Perspectives for the Empirical Research on Law and Language in Hungary}

New advances in the field of linguistics that appeared around the globe arrived only later in Hungary, as the socialist system resisted ideas from the West after World War II. However, in the 1960s the ice was broken: a new periodical, General Linguistic Studies (Általános Nyelvészeti Tanulmányok) was launched in 1963, and in 1967 Ferdinand de Saussure's most influential work, Course in General Linguistics (1916), was published in Hungarian; university courses in linguistics also started up in these years. However, Chomsky's works became available in Hungarian only from the end of the 1970s. As regards research on legal language, Hungarian linguists started to study written legal texts, such as legal norms and court decisions, and realized the need for them to be comprehensible; meanwhile, lawyers considered language to be merely a tool for reaching their legal goals and not worthy of their interest. In 1981, the linguist Sándor Karcsay summarized the initial results of previous studies; he differentiated four layers of Hungarian legal language, in order to reveal the reason for the different levels of comprehensibility of different legal texts.

Several subfields of the 'law and language' movement that developed from the 1970s in the United States of America and some Western European countries also remained unknown in Hungary until the political transition of 1989/1990. However, forensic linguistics was touched upon by Ferenc Nagy at the beginning of the 1980s, and the linguist Miklós Kontra reported on some exceptional cases where linguists were involved as experts in Hungarian legal procedures. Empirical research on Hungarian legal language started in 2000, within the framework of two projects hosted by the Department of Jurisprudence and Sociology of Law, University of Miskolc. These studies fit into the tradition of 'courtroom studies' as one of the most popular research areas in the 'law and language' discipline: what makes them empirical and really valuable is the recording of oral communications in legal circumstances. The recordings were prepared not only in courtrooms, but also during police interrogations.

The first project—entitled 'Language use in legal procedures: Language translation and the nature of fact in the process of establishing legal statements of facts'was conducted between 2000 and 2003 in Miskolc, with the cooperation of lawyers and linguists at the University of Miskolc. The researchers sought to reveal and analyse the establishment of facts and the process of adjudication during the criminal procedure of gathering evidence at the police and at the court, during which lay narratives were translated into facts phrased in the legal register. This is what Jakobson called intra-lingual translation between different codes or registers (in this case: between 'lay' and 'legal' code) within the same language [18]. The aim of the research was twofold: to reveal the linguistic features of the lay and the professional 
ways of speaking, on the one hand, and to examine the influence that the presence of power and coercion in discourse had on the process of the establishment of facts, on the other. The research analysed a given number of legal cases intensively, rather than extensively-i.e.; it did not try to study a lot of cases, but instead to follow a case for as long as possible over the course of the proceedings, in order to gain in-depth knowledge. As regards the findings, it was already clear at the outset that directly applicable results could not be expected, as the project was undertaking basic research with no precedent in Hungary. Therefore, the main objective could 'only' be to raise awareness of a new research area and to inspire further inquiry. However, being interdisciplinary research, the results could be (and in some cases already are) incorporated into the curricula of law and applied linguistics education.

With minor changes, the goals were overwhelmingly achieved. The team carried out unique research in Hungary, and as a result could say that the development of 'law and language' research had finally begun in our country, having been in place in other countries for decades. A further outstanding outcome of the research was that more than $18 \mathrm{~h}$ ' worth of recordings were collected, including 14 and a half hours at police interrogations and $4 \mathrm{~h}$ at court trials. This database enabled both linguistic and legal researchers to go on examining the language used in a legal process or to analyse it according to their viewpoints. The first concrete manifestation of the fulfilment of the objective was a volume of essays and studies published in 2010, in which the research participants summarized the development of legal and linguistic research in English- and German-speaking countries, and analysed the research findings from legal and linguistic aspects [34].

During the empirical research, tape recordings of police and court hearings were prepared with the involvement of law students. Researchers used participant observation as a method developed in cultural anthropology: besides making the tapes, they also wrote down all their observations, some of which would not have been evident from the recordings alone. Permission was needed to make the tape recordings. A detailed written agreement on cooperation was reached with the police headquarters in Miskolc. However, the researchers faced some difficulty in the courts: the leaders of the judiciary had provided only oral permission, and therefore most judges would not allow the hearings to be recorded. This influenced the composition of the resulting database: as mentioned above, it contains far more recordings of police interviews than of court hearings.

At the police station, besides tape recordings of interrogations and confrontations, in-depth interviews were made with the lay and professional people who were taking part in the proceedings. As regards suspects and witnesses, the aim was largely to reveal their ordinary living conditions, education and literacy-and thus to pinpoint their social status in relation to the style of their language use (a relationship revealed by the discipline of sociolinguistics, see [2]). However, it also seemed useful to ask about their impressions of the proceedings, by seeking their opinion of the interrogation officer, and asking whether they understood his/her questions and could talk about anything they considered important in relation to the case. Those police officers who took part in the questioning of suspects were also asked about interrogations in general, as well as about the specific case just recorded. Researchers did not manage to similarly interview the participants in court trials. 
Precise and detailed analysis required the tapes to be transcribed. It was necessary to investigate the various possibilities for transcription that are applied in linguistics and to develop those transcription methods that were most suited to the aims of the different (linguistic and legal) analyses. Originally, the intention was also to use document analysis, which would have meant a comparison of the transcribed versions of the recordings prepared at the police and court hearings, and the official written records. Unfortunately, this comparison could not be carried out, as the official records prepared during police interrogations and at court hearings were not made available to the researchers.

From the several conclusions of the research (see more details in [41: 213-220]), two aspects are highlighted here with regard to understanding legal language. By developing the 'linguistic model of adjudication', it is stressed that in legal proceedings the success of verbal communication governs how effectively the facts can be established. The proceedings cannot be fair from a legal perspective, if they are not also fair from a linguistic, communication perspective. If any problems arise, or if there is any distortion during the interaction between the lay and the legal experts, this will have an impact on the process of establishing the facts, and ultimately on the outcome of the process - most notably, on the judgment. Even before the start of the empirical research, the truth of this was established by the results of American 'courtroom studies'. In respect of Hungarian legal practice, the hypothesis has now been proved by analysis of the tape recordings made during the research.

During analysis of the tape recordings, it was found that information on the rights and obligations of laymen is supplied by police officers and judges during the procedure, as required by law; however, the original aim of the information is not fully achieved. The recordings clearly prove that-although investigators and judges comply with the regulations of the Code on Criminal Procedure and with other legal norms - the mode or fashion of the communication often renders the essence of the warning ineffective, and laymen can barely understand the message. Naturally, this is difficult to prove, as the recordings include the text of the information provided and a caution is indeed issued at the start of each interrogation. So, the claim of unintelligibility is not backed up by the transcripts of the tape recordings; it can only be proved by listening to the recordings themselves. Thus, the practice does meet the strict requirements of law, but the cautions do not fulfil their originally intended function.

The second empirical research was carried out between 2014 and 2018. The title of that project-Linguistic aspects of fair trial: The impact of legal language on the fulfilment of access to justice-includes two key phrases: fair trial and access to justice. The research group, which consisted of lawyers, linguists and computational linguists [48], started with the hypothesis that the (previously detected) intra-lingual translation puts lay people at a disadvantage and hinders their access to justice. Or in other words (as stated above): a legal procedure cannot be fair from a legal perspective, if it is not fair from a linguistic perspective. Another aim of the research was to build a database containing those characteristics of Hungarian written and spoken legal language that are difficult for lay 
people to understand. In order to achieve this aim, new voice recordings were prepared at court hearings in 2017 (unfortunately, this time the members of this project could not sign an agreement with the police). This provided an opportunity to compare the previous and the current Hungarian official practice of delivering information to lay persons about their rights and obligations.

By the end of the project, in 2018, the research group had managed to build up a database containing different types of legal texts. The Miskolc Legal Corpus consists of the following six datasets, representing the three main types of legal texts (statutory, operational and explanatory texts, see: [46]):

1. Codes of law (Criminal Code, Civil Code and the three Procedural Codes),

2. Other acts of Parliament and decrees/regulations,

3. Anonymized judgments of courts,

4. Reasoning of acts of Parliament, course books for law students,

5. Internet forums, and

6. Recordings (and transcripts) of police interrogations and court hearings.

The overall content of the database extends to more than 2 million words, i.e., approximately 150,000 sentences. In the volume containing the closing conference presentations on the project [35], the linguist members of the research group analysed the main features of the different subcorpora, and compared them with a corpus of ordinary language (Szeged Treebank, [7]) comprising business news, newspaper articles, school essays, literature texts and a mixture of professional texts (IT and law). One of the most important assumptions is that legal language differs from ordinary language, as the average sentence in legal language is longer than in ordinary language. The following table indicates that only sentences from legal textbooks and from official explanations are longer than the average sentence produced in 'ordinary language'. The corpus of codes of law contains sentences of almost exactly the same length as in the ordinary-language corpus, while the texts of statutes contain sentences of even shorter average length (Table 1).

Table 1 Average length of sentences in Miskolc Legal Corpus in ascending order [47]

\begin{tabular}{ll}
\hline & $\begin{array}{l}\text { Average length } \\
\text { of sentences }\end{array}$ \\
\hline Transcripts of police and court hearings & 10.39 \\
Other statutes and decrees & 13.90 \\
Chats in legal chatrooms & 14.25 \\
Miskolc Legal Corpus (sum) & $\mathbf{1 6 . 2 1}$ \\
Szeged Treebank (ordinary-language corpus) & $\mathbf{1 7 . 1 4}$ \\
Core statutes (codices) & 17.85 \\
Judgments & 19.56 \\
Explanatory texts (legal textbooks) & 19.83 \\
\hline
\end{tabular}


On the assumption that each layer of legal language has different linguistic features (i.e., legal language is not homogeneous), one of the questions was which types of legal texts are more comprehensible than others. According to the linguistic analyses, the following scale (Fig. 1) was drawn up as regards the intelligibility of legal texts [42: 33].

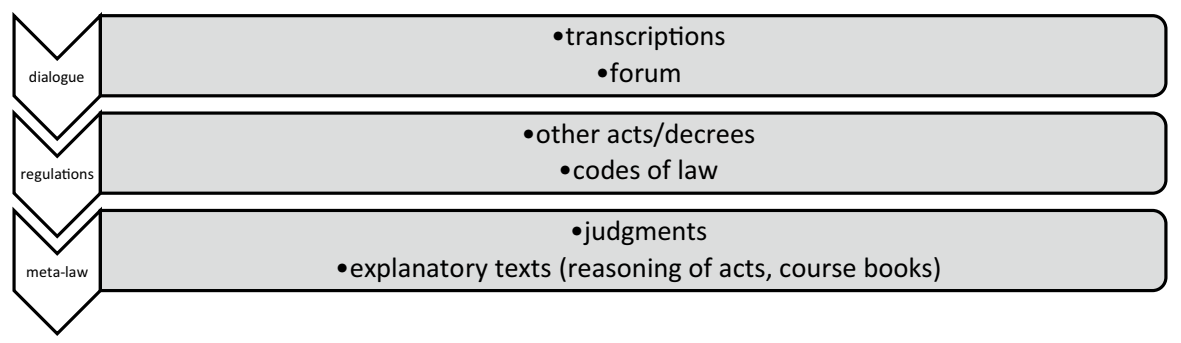

Fig. 1 Comprehensibility of legal texts

This scale shows that-taking different parameters of comprehensibility into account-spoken language in the legal context (at police interrogations and court hearings) and the language of internet forums are the closest to ordinary language, while-perhaps surprisingly_so-called meta-law (court judgments and explanatory texts) is the hardest for lay persons to understand.

\section{Conclusion}

One of the lessons that might be learnt from the Hungarian experience in relation to 'law and language' is the difficulty of separating rigidly the linguistic analysis of legal texts and the legal analysis of the official normative language. Nevertheless, our special issue seeks to show that a critical attitude, in tandem with an interdisciplinary methodology, may lead not only to a blurring of the sharp distinction between lawyers' and linguists' law and language, but also to the creation of a better society, by providing a better grammar for social inclusion and a useful vocabulary for political emancipation.

Acknowledgements Open access funding provided by University of Miskolc.

Open Access This article is licensed under a Creative Commons Attribution 4.0 International License, which permits use, sharing, adaptation, distribution and reproduction in any medium or format, as long as you give appropriate credit to the original author(s) and the source, provide a link to the Creative Commons licence, and indicate if changes were made. The images or other third party material in this article are included in the article's Creative Commons licence, unless indicated otherwise in a credit line to the material. If material is not included in the article's Creative Commons licence and your intended use is not permitted by statutory regulation or exceeds the permitted use, you will need to obtain permission directly from the copyright holder. To view a copy of this licence, visit http://creativecommons.org/licen ses/by/4.0/. 


\section{References}

\section{Literature}

1. Aristotle, H.W. 1926. The "Art" of Rhetoric, transl. by J. H. Freese, London, New York: William Heinemann, G. P. Putnam's Sons.

2. Bernstein, Basil. 1971. Class, codes and control: theoretical studies towards a sociology of language. London: Routledge \& Kegan Paul.

3. Bobbio, Norberto. 1950. Interpretazioni anglosassoni della filosofia del diritto. Rivista internazionale di filosofia del diritto 35(1): 90-101.

4. Bodig, Matyas. 2001. Megértés, racionalitás, gyakorlati ész. Jogfilozófiai reflexiók a gadameri hermenutikáról' [Understanding, rationality, practical reason]. In: Ius Humanum. Ember alkotta jog. Mühelytanulmányok, ed. Szabó, Miklós, 223-206. Miskolc: Bíbor.

5. Noam, Chomsky. 1971. Deep structure, surface structure, and semantic interpretation. In Semantics, ed. D. Steinberg and L. Jacobovitz, 183-216. Cambridge: Cambridge University Press.

6. Noam, Chomsky. 2005. Language and Mind. Cambridge: Cambridge University Press.

7. Csendes, Dóra., Csirik, János., Gyimóthy, Tibor., and Kocsor, András. 2005. The Szeged Treebank. In: Václav Matoušek et al. eds. Proceedings of the 8th international conference on text, speech and dialogue (TSD 2005), pp. 123-131, Karlovy Vary, Czech Republic: Springer LNAI 3658.

8. Csiky, Kálmán. 1899. Werböczy István és Hármaskönyve [Stephen Werböczy and his Tripartitum]. Budapest: Franklin.

9. David, René. 1964. Les grands systèmes de droit contemporains. Paris: Dalloz.

10. Eco, Umberto. 1993. Traduction et langue parfaite. Lecture at the Conference held in Arles, 14 November 1993: ATLAS Assises de la traduction littéraire en Arles. pp. 191-207. http://www. atlas-citl.org/wp-content/plugins/pdfjs-viewer-shortcode/pdfjs/web/viewer.php?file=http:// www.atlas-citl.org/wp-content/uploads/pdf/10actes.pdf\#page $=8 \&$ pagem ode $=$ bookm arks\&zoom $=$ auto,0,0\&download $=$ false $\&$ print $=$ false $\&$ openfile $=$ false.

11. Pashukanis, Evgeny. B. 2003. Law and Marxism: A General Theory. [1924] London: Transaction Publishers. https://legalform.files.wordpress.com/2017/08/pashukanis-general-theory-1924.pdf.

12. Fikentscher, Wolfgang. 1977. Methoden des Rechts in vergleichender Darstellung IV Dogmatischer Teil. Tübingen: Mohr Siebeck.

13. Földi, András. 2020. False friends and some other phenomena reflecting the historical determination of the terminology of Hungarian private law. In: Hungarian Language and Law. Paksy, Szabó, Vinnai (eds.) International Journal for the Semiotics of Law.

14. Fuglinszky, Ádám, Somssich, Réka. 2020. Language-bound terms-term-bound languages: the difficulties of translating a national civil code into a lingua franca. In: Hungarian Language and Law. Paksy, Szabó, Vinnai (eds.) International Journal for the Semiotics of Law.

15. Gai 1904. Institutiones: Or Institutes Of Roman Law By Gaius, trans. by Edward Poste, Oxford: Clarendon.

16. Gedeon, Magdolna. A magyar jogi nyelv történetéről. [On the History of Hungarian Legal Language]. In: A törvény szavai [The Words of Law]. eds. Szabó, Vinnai, 199-222. Bíbor: Miskolc.

17. Hamza, Gábor. 2002. Az európai magánjog fejlödése [The Development of European Private Law]. Budapest: Nemzeti Tankönyvkiadó.

18. Jakobson, Roman. 1959. On linguistic aspects of translation. In On Translation, ed. R.A. Brower, 232-239. Cambridge: Harvard U.P.

19. Kis, János. 2004. A politika mint erkölcsi probléma. [The Politics as Moral Problem], Budapest: Irodalom Kft.

20. Klaudy, Kinga. 2003. Languages in translation. Lectures on the theory, teaching and practice of translation. Budapest: Scholastica.

21. Körtvélyesi, Zsolt. 2020. Nation, nationality, and national identity: Uses, misuses, and the Hungarian case of external ethnic citizenship. In: Hungarian Language and Law. Paksy, Szabó, Vinnai (eds.) International Journal for the Semiotics of Law.

22. Küpper, Herbert. 2020. Terminology in the new Hungarian Civil Code: Reception of Hungarian sources and foreign models. In: Hungarian Language and Law. Paksy, Szabó, Vinnai (eds.) International Journal for the Semiotics of Law. 
23. Márkus, Dezső. 1898-1907. Magyar jogi lexikon [Hungarian Legal Lexicon]. Vol. 1-6. Budapest: Pallas, pp. 1898-1907.

24. MTA (Hungarian Academy of Science). 1951. Sztálin nyelvtudományi munkái és a magyar tudomány [Stalin's works on linguistics and Hungarian sciences]. 1 Magyar Tudományos Akadémia I. és II. Osztályának Közleményei, p. 1.

25. Ost, François. 2014. Law as Translation. In The method and culture of comparative law: essays in honour of mark van Hoecke, ed. Maurice Adam and Dirk Heirbaut, 69-86. Oxford: Hart.

26. Paksy, Mate. 2020. Toward a better understanding of peripheral nation-building strategies: a critical comparison of the Austro-Hungarian Ausgleich and the Canadian British North America Act (1867). In: Hungarian Language and Law. Paksy, Szabó, Vinnai (eds.) International Journal for the Semiotics of Law.

27. Parthenopeus, Raymundus 1926. Summa legum brevis levis et utilis. [1506] Cracoviae I, Łaski Weimar, Gál I.

28. Péter, László. 2012. Hungary’s long nineteenth century: Constitutional and democratic traditions in a European perspective. Collected studies, ed. by Lojkó Miklós Leiden, Boston: Brill.

29. Révész, Béla. 2020. Draft for understanding the changes in the language and communication of the secret service in the 20th century's Hungary. In: Hungarian Language and Law. Paksy, Szabó, Vinnai (eds.) International Journal for the Semiotics of Law.

30. Searle, John R. 1972. 'Chomsky's Revolution in Linguistics' XVII. The New York Review of Books. pp. 16-24.

31. Stalin, Joseph V. 1950. Marxism and Problems of Linguistics, Moscow: Foreign Languages Publishing House. www.marxists.org/reference/archive/stalin/works/1950/jun/20.htm.

32. Szabó, Imre. 1976. The notion of law. 18 Acta Juridica Academiae Scentiarum Hungaricae. pp. 263-272.

33. Szabó, Miklós. 2004. Law as Translation. Archiv für Rechts- und Sozialphilosophie, Beiheft Nr. 91. Pluralism and Law. vol. 4: Legal Reasoning. ed. by Soeteman, A., pp. 60-68.

34. Szabó, Miklós (ed.). 2010. Nyelvében a jog [The Law in its Language]. Bíbor: Miskolc.

35. Szabó, Miklós, and Vinnai, Edina eds. 2018. A törvény szavai [The Words of Law]. Bíbor: Miskolc.

36. Takács, Péter. 1995. Joguralom és jogállam. Antológia a Rechtsstaat és a Rule of Law irodalmának köréból [Rule of Law qnd Rechtsstaat: Selected Papers] Budapest: ELTE ÁJK, Tempus.

37. Takács, Péter. 2020. Renaming states-A case study: changing the name of the Hungarian state in 2011. Its background, reasons, and aftermath. In: Hungarian Language and Law. Paksy, Szabó, Vinnai (eds.) International Journal for the Semiotics of Law.

38. Tindale, Christopher W. 1996. Fallacies in transition: an assessment of the pragmadialectical perspective. 18 Informal Logic. pp. 17-33.

39. Tomaschek, Johann A. 1884. Über eine in Oesterreich in der ersten Hälfte des vierzehnten Jahrhunderts geschriebene Summa legum incerti auctoris und ihr Quellenverhältniss zu dem Stadtrechte von Wiener-Neustadt und dem Werbözischen Tripartitum. Sitzungsberichte der Akademie der Wissenschaften in Wien. Philosophisch-historische Klasse, 105/5.

40. Veress, Emőd. 2020. Language and law in multiethnic societies: the case of Transylvania. In: Hungarian Language and Law. Paksy, Szabó, Vinnai (eds.) International Journal for the Semiotics of Law.

41. Vinnai, Edina. 2017. Jog és nyelv határán. A jogi nyelvhasználat nemzetközi és hazai kutatása. [On the Edge of Law and Language. International and Hungarian Research on Legal Language Usage.] Budapest: Gondolat.

42. Vincze, Veronika: A Miskolc Jogi Korpusz nyelvi jellemzői. [Linguistic Characteristics of Miskolc Legal Corpus] In: Szabó, Vinnai (eds.) A törvény szavai [The Words of Law]. 9-36. Bíbor: Miskolc.

43. Voloshinov, V. N. 1986. Marxism and the Philosophy of Language, transl. by L. Matejka, I. R. Titunik, Cambridge, MA-London: Harvard U. P.

44. Vyshinsky, Andrei Y. 1948. The Law of the Soviet State [1936], transl. by Hugh W. Babb, New York: The Macmillan Company 1948. https://legalform.files.wordpress.com/2019/03/vyshinskythe-law-of-the-soviet-state.pdf.

45. Werbőczy, István. Tripartitum. Opus Iuris Consuetudinarii Inclyti Regni Hungariae. https://reade r.digitale-sammlungen.de/en/fs1/object/display/bsb10144364_00001.html.

46. Ződi, Zsolt. 2017. Jogi szövegtípusok [Types of legal texts] 1 Magyar Jogi Nyelv, vol. 2, pp. 20-29.

47. Ződi, Zsolt. 2019. The limits of plain legal language: understanding the comprehensible style in law. International Journal of Law in Context, 15(03): 246-262. 


\section{Data bases}

48. https://sites.google.com/site/otkamiskolcen/members

Publisher's Note Springer Nature remains neutral with regard to jurisdictional claims in published maps and institutional affiliations. 